Life Science 10 (2) (2021)

Life Science

http://journal.unnes.ac.id/sju/index.php/LifeSci

\title{
Struktur Komunitas Makrozoobentos di Perairan Pesisir Kelurahan Mangunharjo sebagai Bioindikator Kualitas Perairan
}

\section{Risna Gina Sofiyani ${ }^{凶}$, Max Rudolf Muskananfola, Bambang Sulardiono}

Jurusan Manajemen Sumberdaya Perairan, Fakultas Perikanan dan Ilmu Kelautan Universitas Diponegoro, Semarang, Indonesia

\begin{tabular}{l}
\hline Info Artikel \\
\hline Diterima: 1 September \\
2021 \\
Disetujui: 30 September \\
2021 \\
Dipublikasikan: 30 \\
November 2021 \\
\hline Keywords: \\
abundance; macrozoobenthos; \\
Mangunharjo village; \\
sediment
\end{tabular}

\begin{abstract}
The coastal waters of Mangunharjo Village, Tugu, Semarang City are located in a densely populated residential area, and many activities of people around it. These activities can cause a decrease in water quality which will impact the biota. This study aims to determine the structure of the macrozoobenthos community, determine the level of pollution that occurs and determine the most affecting factors of macrozoobenthos community in the coastal waters of Mangunharjo Village. This research using the purposive sampling method. Result find that there were 22 species of makrozoobenthos. The diversity index value $\left(H^{\prime}\right)$ is categorized as moderate to low with a mean value of $H^{\prime}=0,79$. The uniformity index value (E) indicates a depressed to stable condition with a mean value of $E=0,52$. The dominance index value $(C)$ indicates that there are species that dominates significantly. The similarity index value is dominant in the low category. The status of pollution in the coastal waters of Mangunharjo Village is classified as polluted water. The factors that most influence the abundance of macrozoobenthos in the coastal waters of Mangunharjo Village are water temperature, loam and clay sediment texture with a correlation value of 0,$597 ; 0,474$ and 0,453 .
\end{abstract}

\begin{abstract}
Abstrak
Perairan pesisir Kelurahan Mangunharjo, Kecamatan Tugu, Kota Semarang berada pada kawasan pemukiman padat penduduk yang banyak terdapat aktivitas warga di sekitarnya. Aktivitas - aktivitas tersebut dapat menyebabkan penurunan kualitas air yang akan berdampak pada biota. Tujuan penelitian ini adalah untuk mengetahui struktur komunitas makrozoobentos, mengetahui tingkat pencemaran yang terjadi dan mengetahui faktor yang paling mempengaruhi komunitas makrozoobentos di perairan pesisir Kelurahan Mangunharjo. Penelitian ini menggunakan metode purposive sampling. Hasil penelitian menemukan 22 spesies makrozoobentos. Nilai Indeks Keanekaragaman $\left(\mathrm{H}^{\prime}\right)$ dikategorikan sedang hingga rendah dengan nilai rerata $H^{\prime}=0,79$. Nilai Indeks Keseragaman $(E)$ mengindikasikan kondisi yang tertekan hingga stabil dengan nilai rerata $\mathrm{E}=0,52$. Nilai Indeks Dominansi $(C)$ menunjukkan adanya jenis yang mendominansi secara signifikan. Nilai Indeks Kesamaan dominan berada dalam kategori yang rendah. Status pencemaran di perairan pesisir Kelurahan Mangunharjo tergolong tercemar. Faktor yang paling berpengaruh terhadap kelimpahan makrozoobentos di perairan pesisir Kelurahan Mangunharjo adalah suhu air, tekstur sedimen lempung dan tekstur sedimen liat dengan nilai korelasi 0,$597 ; 0,474$ dan 0,453 .
\end{abstract}

(C) 2021 Universitas Negeri Semarang

$\square$ Alamat korespondensi:

Jurusan Manajemen Sumberdaya Perairan, Universitas Diponegoro

p-ISSN 2252-6277

E-mail: risnaginasofivani7@gmail.com

e-ISSN 2528-5009 


\section{PENDAHULUAN}

Kawasan pesisir adalah wilayah peralihan antara daratan dan lautan. Kawasan pesisir berupa daerah yang terletak di sepanjang garis pantai dan masih dipengaruhi oleh proses alami dari darat maupun kegiatan manusia. Menurut Suhendra et al. (2019), kawasan pesisir merupakan daerah tempat bertemunya antara daratan dan air laut yang didalamnya terjadi interaksi baik faktor fisik, kimia, dan biologi. Wilayah pesisir memiliki kekayaan sumberdaya alam baik hayati dan non-hayati, serta jasa lingkungan. Wilayah ini strategis untuk dikembangkan bagi kegiatan ekonomi dan jasa lingkungan kelautan (Nessa et al., 2002 dalam Ernawati et al., 2013).

Kelurahan Mangunharjo merupakan kelurahan di wilayah Kecamatan Tugu, Kota Semarang, Provinsi Jawa Tengah dengan luas 4,00 $\mathrm{km}^{2}$. Kawasan di perairan pesisir Kelurahan Mangunharjo merupakan daerah bertemunya air laut dan air tawar, umumnya dimanfaatkan masyarakat untuk melakukan aktivitas ekonomi yaitu kegiatan perikanan seperti tambak budidaya dan objek wisata yaitu hutan mangrove. Kegiatan tersebut dalam pemanfaatan perairan secara berlebihan dapat menyebabkan terjadinya pencemaran (Kolaya et al., 2014). Kawasan pesisir Kelurahan Mangunharjo saat ini mengalami ancaman yang berasal dari alam dan manusia. Ancaman yang berasal dari alam meliputi abrasi dan sedimentasi di muara. Sedangkan ancaman dari manusia meliputi alih fungsi lahan untuk kegiatan budidaya dan pemukiman, eksploitasi hutan mangrove, pariwisata dan kegiatan industri. Kegiatan tersebut tentunya akan menghasilkan limbah dan tidak dipungkiri adanya pembuangan limbah rumah tangga secara sembarangan berupa sampah organik atau anorganik ke perairan pesisir Kelurahan Mangunharjo. Aktivitas - aktivitas tersebut dapat menyebabkan penurunan kualitas di perairan pesisir Kelurahan Mangunharjo, yang akan berdampak pada biota yang hidup di perairan tersebut. Berubahnya kualitas suatu perairan akan berpengaruh terhadap struktur komunitas makrozoobentos seperti keanekaragaman bentos yang hidup di dasar perairan tersebut. Perairan dengan kualitas baik akan memiliki keanekaragaman jenis yang tinggi dan perairan tercemar maka sebaliknya yaitu akan memiliki keanekaragaman jenis yang rendah. Akan tetapi dengan melihat keanekaragaman makrozoobentos saja tidak cukup untuk menentukan kualitas perairan, maka dari itu harus dilihat juga dari faktor fisika kimia perairan (Pranoto, 2017).

Makrozoobentos merupakan organisme akuatik yang hidup menetap di dasar perairan. Makrozoobentos memiliki tingkat pergerakan yang lambat. Habitat dan cara hidup tersebut menyebabkan makrozoobentos sering digunakan sebagai indikator biologi pencemaran perairan. Menurut Sahidin et al. (2014), makrozoobentos merupakan organisme akuatik yang hidup di permukaan atau dalam sedimen perairan. Pergerakan makrozoobentos relatif menetap pada suatu substrat tertentu sehingga lebih sensitif terhadap gangguan lingkungan perubahan kualitas air dan sedimen. Makrozoobentos cukup peka terhadap perubahan kualitas perairan yang akan mempengaruhi kelimpahan, keanekaragaman dan distribusinya. Berdasarkan hal diatas dilakukan penelitian untuk mengetahui struktur komunitas makrozoobentos di perairan pesisir Kelurahan Mangunharjo, mengetahui tingkat pencemaran yang terjadi di perairan pesisir Kelurahan Mangunharjo berdasarkan 
indikator kimia dan fisika, dan mengetahui faktor yang berpengaruh terhadap komunitas makrozoobentos di perairan pesisir Kelurahan Mangunharjo.

\section{METODE}

Penelitian ini dilaksanakan pada bulan Februari 2021 di perairan pesisir Kelurahan Mangunharjo, Semarang. Pengambilan sampel dilakukan menggunakan metode purposive sampling. Purposive sampling merupakan suatu teknik pengambilan sampling berdasarkan ciri - ciri khusus atau pertimbangan tertentu sesuai kriteria kondisi perairan. Pada penelitian ini terdapat 6 stasiun pada perairan Kelurahan Mangunharjo yaitu laut, pantai, muara, mangrove, sungai dan tambak dengan 5 kali pengulangan di setiap stasiunnya.

\section{Pengambilan Sampel Makrozoobentos dan Sedimen}

Makrozoobentos dan sedimen diambil dengan menggunakan alat Ekman Grab dengan ukuran luas bukaan $15 \times 15 \mathrm{~cm}^{2}$. Cara kerja Ekman Grab yaitu mengeruk substrat, selanjutnya substrat diayak sehingga makrozoobentos akan terpisah dari substrat dan kotoran. Sampel sedimen dimasukkan ke dalam plastik zipper untuk kemudian dilakukan analisis tekstur substrat di Laboratorium PSDIL Undip sedangkan sampel makrozoobentos kemudian diawetkan dengan larutan formalin $10 \%$. Selanjutnya dilakukan proses identifikasi makrozoobentos dengan cara mengamati ciri - ciri morfologi yang mengacu pada buku identifikasi makrozoobentos.

\section{Pengambilan Sampel Variabel Fisika - Kimia Perairan}

Parameter yang di analisis adalah suhu, kedalaman, kecerahan, kekeruhan, kecepatan arus, salinitas, substrat, derajat keasaman, dan DO. Pengukuran variabel yang dapat dilakukan langsung di lokasi pengambilan sampel yaitu suhu, kedalaman, kecerahan, kecepatan arus, dan salinitas, derajat keasaman, DO. Sedangkan Pengukuran variabel yang dilakukan di Laboratorium PSDIL Undip adalah kekeruhan dan substrat.

\section{Analisis Data}

Makrozoobentos yang telah diidentifikasi kemudian dilakukan perhitungan indeks keanekaragaman Shannon-Wiener $\left(\mathrm{H}^{\prime}\right)$, indeks keseragaman (E), indeks dominasi (C), dan indeks kesamaan (S). Analisis tekstur sedimen menggunakan metode Buchanan (1971) dalam Holme \& McIntyre (1984) yaitu metode ayak kering (sieve analysis) pada saringan bertingkat kemudian diplotkan dan dilakukan penamaan sesuai dengan segitiga Sheppard penamaan sedimen. Analisis PCA menggunakan software SPSS 25 digunakan untuk mengetahui pengaruh dari variabel fisika kimia dan tekstur sedimen terhadap kelimpahan makrozoobentos.

\section{HASIL DAN PEMBAHASAN}

Hasil perhitungan indeks keanekaragaman, keseragaman dan indeks dominasi per stasiun penelitian disajikan dalam Tabel 1, sedangkan hasil perhitungan indeks kesamaan dapat dilihat pada Tabel 2. 
Tabel 1. Indeks Keanekaragaman, Keseragaman dan Dominasi

\begin{tabular}{cccc}
\hline \multirow{2}{*}{ Stasiun } & \multicolumn{3}{c}{ Indeks } \\
\cline { 2 - 4 } & $\mathbf{H}^{\prime}$ & $\mathbf{E}$ & $\mathbf{C}$ \\
\hline I & 0,64 & 0,92 & 0,56 \\
II & 1,51 & 0,69 & 0,28 \\
III & 0,93 & 0,39 & 0,62 \\
IV & 0,77 & 0,48 & 0,51 \\
V & 0,84 & 0,61 & 0,54 \\
VI & 0,06 & 0,05 & 0,98 \\
\hline
\end{tabular}

Keterangan: H": indeks keanekaragaman, E: indeks keseragaman, C: indeks dominasi

Tabel 2. Indeks Kesamaan

\begin{tabular}{ccccccc}
\hline Stasiun & I & II & III & IV & V & VI \\
\hline I & $\mathrm{X}$ & $18,18 \%$ & $0,00 \%$ & $0,00 \%$ & $0,00 \%$ & $0,00 \%$ \\
II & & $\mathrm{X}$ & $30,00 \%$ & $28,57 \%$ & $30,77 \%$ & $16,67 \%$ \\
III & & & $\mathrm{X}$ & $0,00 \%$ & $0,00 \%$ & $0,00 \%$ \\
IV & & & & $\mathrm{X}$ & $88,89 \%$ & $25,00 \%$ \\
V & & & & & $\mathrm{X}$ & $28,57 \%$ \\
VI & & & & & & $\mathrm{X}$ \\
\hline
\end{tabular}

Keterangan:

Kategori Tinggi

Kategori Sedang

Kategori Rendah

Makrozoobentos yang ditemukan pada penelitian ini yaitu terdapat total dua puluh dua spesies, terdapat 3 spesies dengan kelimpahan terbanyak yaitu Littoraria scabra sebanyak 1290,32 ind/ $\mathrm{m}^{2}$, Tarebia granifera sebanyak 799,17 ind $/ \mathrm{m}^{2}$ dan Cerithidea cingulata sebanyak 2863,68 ind $/ \mathrm{m}^{2}$. Littoraria scabra ditemukan melimpah pada ekosistem pantai yang berdekatan dengan area mangrove. Littoraria scabra lebih banyak menempel pada akar mangrove dan cenderung bergerombol. Littoraria memliki pola distribusi mengelompok dan lebih menyukai mangrove dengan batang pendek yang ranting serta akarnya menjulur sehingga akan memudahkan spesies ini untuk berpindah tempat mencari makan (Sujatmiko \& Aunurohim, 2013). Littoraria scabra memiliki ciri-ciri yaitu bentuk cangkangnya bulat dengan apex meruncing. Ukuran cangkang relatif kecil berkisar antara 1,5-2,5 cm. Warna dasar cangkang yaitu kuning kecoklatan serta terdapat pola garis coklat gelap. Menurut Poutiers (1998) dalam Nuruddin et al. (2015), Littoraria scabra memiliki warna kuning pucat pada aperture, outer lip berwarna kuning kehitaman, dan memiliki warna putih pucat pada inner lip.

Tarebia granifera merupakan gastropoda dari famili Thiaridae. Spesies ini memiliki morfologi cangkang berbentuk bulat memanjang dengan apex yang runcing. Cangkangnya berwarna coklat muda hingga coklat pucat. Panjang cangkangnya berkisar $1-3 \mathrm{~cm}$. Permukaan cangkang kasar dan terdapat tonjolan - tonjolan kecil. Spesies ini dapat ditemukan di perairan yang terkena pasang surut yang salinitasnya tidak terlalu tinggi, sungai, danau, dan kanal. Tarebia granifera hidup dengan memakan detritus, alga dan diatom yang berada di sekitarnya (Latupapua, 2011 dalam Viza, 2018).

Cerithidea cingulata merupakan jenis gastropoda yang memiliki ciri - ciri cangkangnya berwarna coklat hingga hitam. Cangkang berbentuk kerucut dengan apex yang sangat tajam. Permukaan cangkang terasa kasar. Spesies ini ditemukan sangat melimpah bergerombol di area tambak dengan 
substrat yang berlumpur. Menurut Yusuf dan Gentur (2004) dalam Afif et al. (2014), C. cingulata dapat ditemukan di perairan payau, muara sungai dan area tambak. Spesies ini hidup secara mengelompok dalam jumlah yang besar dan memiliki pola perkembangbiakan yang cepat.

Hasil indeks keanekaragaman $\left(\mathrm{H}^{\prime}\right)$ pada stasiun I, III, IV, V, VI menunjukkan tingkat keanekaragaman yang rendah dimana kestabilan komunitas rendah dan tiap spesies memiliki jumlah individu yang rendah. Kestabilan komunitas yang rendah menandakan bahwa ekosistem sudah dalam keadaan tercemar berat. Hal ini sesuai dengan kategori nilai indeks keanekaragaman oleh ShannonWiener dalam Rachmawaty (2011) yang menyatakan bahwa apabila $\mathrm{H}^{\prime}<1$, artinya keanekaragaman rendah dan menandakan ekosistem telah tercemar berat. Hasil indeks keanekaragaman pada stasiun II menunjukkan nilai $H^{\prime}=1-3$, yaitu termasuk kategori tercemar sedang dimana kestabilan komunitas sedang. Kestabilan komunitas yang sedang merupakan kondisi komunitas yang labil, yaitu mudah berubah apabila terjadi perubahan lingkungan walau dalam skala kecil (Ponk-Masak, 2006 dalam Purnami et al., 2010). Secara keseluruhan indeks keanekaragaman pada perairan pesisir Kelurahan Mangunharjo berada dalam kategori tercemar sedang hingga berat. Hal ini dikarenakan banyaknya aktivitas warga sekitar di sepanjang pesisir yang menyebabkan lingkungan menjadi tercemar. Aktivitas masyarakat antara lain yaitu perahu nelayan yang berlalu lalang dan seringkali membuang oli/solar pada perairan, adanya pembuangan sampah plastik secara sembarangan sehingga menumpuk di pinggiran pesisir. Menurut Meisaroh et al. (2019), nilai indeks keanekaragaman yang rendah dipengaruhi oleh faktor lingkungan sekitar sehingga terjadi penurunan kualitas air.

Hasil indeks keseragaman (E) yang didapat secara keseluruhan memiliki kategori keseragaman rendah hingga tinggi. Stasiun III, IV dan V mempunyai nilai keseragaman dibawah 0,5 . Nilai tersebut terbilang rendah dan dapat diartikan bahwa jumlah individu tiap jenisnya sedikit. Semakin rendah indeks keseragaman mengindikasikan penyebaran jumlah individu tiap jenis yang tidak merata, cenderung adanya jenis tertentu yang mendominasi dalam suatu ekosistem (Odum, 1998). Nilai E dalam kategori sedang diperoleh pada stasiun II dan V karena memiliki rentang nilai 0,50< $\mathrm{E} \leq 0,75$. Menurut Krebs (1985), nilai indeks keseragaman 0,50< $\mathrm{E} \leq 0,75$ termasuk dalam kategori tingkat keseragaman yang sedang dan menandakan kondisi komunitas yang labil. Stasiun I memiliki kategori keseragaman yang tinggi karena nilai $\mathrm{E}$ yang diperoleh mendekati 1 yang artinya kemerataan antar spesies relatif merata atau jumlah individu masing- masing spesies relatif sama. Menurut Budi et al. (2013), indeks keseragaman sebagai pendugaan yang baik untuk menentukan dominasi suatu lingkungan. Apabila terdapat satu atau beberapa jenis yang melimpah maka nilai indeks keseragaman akan rendah.

Nilai indeks dominasi (C) yang diperoleh secara keseluruhan menunjukkan nilai (C) dalam kategori tinggi yaitu $\mathrm{C}>0,5$. Dominasi jenis yang tinggi mengindikasikan ekosistem tersebut terjadi ketidakseimbangan populasi. Ketidakseimbangan populasi dalam suatu ekosistem maka dapat dikatakan ekosistem tersebut tercemar. Adanya dominasi spesies menunjukkan suatu lingkungan memiliki kekayaan jenis yang rendah dan sebaran spesies tidak merata sehingga dalam lingkungan 
yang diamati terdapat spesies yang mendominasi spesies lainnya (Purnama et al., 2001 dalam Munandar et al., 2016).

Nilai indeks kesamaan yang diperoleh secara keseluruhan berkisar antara 0,00\% - 88,89\%, yang menunjukkan indeks kesamaan dalam kategori rendah hingga tinggi. Indeks kesamaan yang rendah terjadi karena adanya perbedaan karakter habitat antar stasiun yang menonjol, begitu pula sebaliknya apabila karakter habitat antar stasiun hampir sama maka nilai indeks kesamaan akan tinggi. Menurut Purnami et al. (2010), indeks similaritas atau indeks kesamaan merupakan suatu bentuk indeks biologi yang dapat menunjukkan seberapa besar tingkat kesamaan struktur komunitas suatu ekosistem dengan yang lainnya.

Hasil perhitungan fraksi sedimen dapat dilihat pada Tabel 3, sedangkan pengukuran variabel fisika kimia yang diperoleh antar stasiun dapat dilihat pada Tabel 4. Hasil pengukuran indikator fisika kimia perairan dibandingkan dengan KepmenLH Nomor 51 Tahun 2004 tentang Baku Mutu Air Laut untuk stasiun I, III dan VI serta PP Nomor 82 Tahun 2001 tentang Pengelolaan kualitas Air dan Pengendalian Pencemaran Air untuk stasiun II, IV dan V.

Tabel 3. Hasil Perhitungan Fraksi Sedimen

\begin{tabular}{ccccc}
\hline \multirow{2}{*}{ Stasiun } & \multicolumn{3}{c}{ Fraksi Sedimen } & \multirow{2}{*}{ Keterangan } \\
\cline { 2 - 4 } & Sand (\%) & Silt (\%) & Clay (\%) & \\
\hline I & 84,68 & 11,18 & 4,14 & Pasir Berlempung \\
II & 82,34 & 14,89 & 2,77 & Pasir Berlempung \\
III & 85,47 & 11,56 & 2,97 & Pasir Berlempung \\
IV & 63,69 & 18,42 & 17,89 & Lempung Berpasir \\
V & 86,61 & 11,17 & 2,22 & Pasir Berlempung \\
VI & 59,05 & 22,80 & 18,15 & Lempung Berpasir \\
\hline
\end{tabular}

Tabel 4. Hasil Pengukuran Variabel Fisika Kimia antar Stasiun di Perairan Pesisir Kelurahan Mangunharjo, Semarang.

\begin{tabular}{ccccccc}
\hline Variabel Fisika & \multicolumn{7}{c}{ Stasiun Penelitian } \\
\cline { 2 - 7 } Kimia Perairan & I & II & III & IV & V & VI \\
\hline Suhu $\left({ }^{\circ} \mathrm{C}\right)$ & 28,08 & 29,34 & 30,16 & 29,48 & 29,60 & 30,28 \\
Kedalaman $(\mathrm{m})$ & 1,70 & 0,78 & 0,59 & 0,40 & 0,75 & 0,46 \\
Kecerahan $(\mathrm{cm})$ & 24,3 & 12,8 & 22,6 & 10,3 & 15,3 & 12,5 \\
Kekeruhan $(\mathrm{NTU})$ & 57,28 & 132 & 32,92 & 88,3 & 60,04 & 34,84 \\
Kec. Arus (m/s) & 0,16 & 0,19 & 0,11 & 0,10 & 0,17 & 0,07 \\
Salinitas $\left({ }^{\circ} / \mathrm{oo}\right)$ & 10 & 7,2 & 17 & 0 & 0 & 14,6 \\
pH & 6,27 & 6,39 & 6,41 & 6,31 & 6,39 & 6,41 \\
DO (mg/L) & 8,50 & 9,20 & 8,64 & 9,06 & 9,02 & 8,68 \\
\hline
\end{tabular}

Berdasarkan hasil pengukuran suhu yang diperoleh, dapat disimpulkan bahwa perairan pesisir Kelurahan Mangunharjo mempunyai suhu berkisar antara $28,08-30,28{ }^{\circ} \mathrm{C}$. Nilai suhu yang diperoleh termasuk dalam kategori normal, dikarenakan kisaran suhu normal berdasarkan baku mutu yakni 25 $31{ }^{\circ} \mathrm{C}$. Suhu merupakan faktor penting yang berpengaruh terhadap kelangsungan hidup biota baik pergerakan maupun penyebarannya. Suhu juga berpengaruh terhadap aktivitas metabolisme makrozoobentos. Suhu perairan yang rendah dapat memperlambat proses metabolisme dalam tubuh makrozoobentos, hal ini berlaku sebaliknya yaitu suhu yang tinggi akan mempercepat proses 
metabolisme dan dapat merusak enzim serta reaksi-reaksi dalam tubuh makrozoobentos. Menurut Widyastuti (2013) dalam Nurlinda et al. (2019), kisaran suhu yang baik untuk pertumbuhan makrozoobentos yaitu $25-32{ }^{\circ} \mathrm{C}$. Berdasarkan pengukuran suhu yang sudah dilakukan dapat dikatakan bahwa pada perairan pesisir Kelurahan Mangunharjo memiliki suhu yang masih dalam kisaran normal menurut baku mutu air dan masih berada dalam batas normal untuk mendukung kehidupan makrozoobentos.

Berdasarkan hasil pengukuran kedalaman yang didapat, dapat disimpulkan bahwa pada perairan pesisir Kelurahan Mangunharjo, Kota Semarang mempunyai kedalaman berkisar antara 0,40 1,70 m. Stasiun dengan nilai kedalaman tertinggi yaitu stasiun I yang merupakan wilayah laut, sedangkan yang paling dangkal yaitu stasiun IV yang merupakan area mangrove. Kedalaman perairan berpengaruh terhadap kelimpahan jenis makrozoobentos. Semakin dalam dasar suatu perairan, maka akan semakin sedikit kelimpahan jenis makrozoobentos karena hanya makrozoobentos tertentu yang dapat beradaptasi di perairan yang dalam (Odum, 1996 dalam Ulfah et al., 2012). Kedalaman perairan juga berkaitan terhadap kadar oksigen yang dibutuhkan oleh biota seperti makrozoobentos. Semakin dalam suatu perairan maka kadar oksigen akan semakin sedikit. Menurut Sverdrup et al. (1942) dalam Simanjuntak (2007), dengan bertambahnya kedalaman maka proses fotosintesis semakin kurang efektif yang kemudian akan terjadi penurunan kadar oksigen terlarut sampai pada suatu kedalaman yang disebut "Compensation Depth". Batasan minimum dan maksimum kedalaman suatu perairan dalam KepmenLH Nomor 51 Tahun 2004 dan PP Nomor 82 Tahun 2001 tidak tertera, dikarenakan ukuran kedalaman perairan tidak terlalu berpengaruh terhadap pencemaran, tetapi berpengaruh terhadap kehidupan makrozoobentos.

Berdasarkan hasil pengukuran kecerahan yang diperoleh, dapat disimpulkan bahwa perairan pesisir Kelurahan Mangunharjo mempunyai nilai kecerahan berkisar antara 10,3 - 24,3 cm. Nilai kecerahan yang diperoleh termasuk dalam kategori buruk, dikarenakan nilai kecerahan berdasarkan baku mutu yang baik yaitu $>600 \mathrm{~cm}$. Kecerahan perairan dipengaruhi oleh bahan organik seperti plankton, jasad renik, dan detritus juga oleh bahan anorganik seperti partikel lumpur dan pasir yang melayang dalam kolom perairan (Zahidin, 2008 dalam Choirudin et al., 2014). Kecerahan perairan tergantung pada warna dan kekeruhan perairan, apabila kecerahan rendah maka dapat mengakibatkan terganggunya sistem osmoregulasi organisme akuatik seperti makrozoobentos. Sistem osmoregulasi yang terganggu diantaranya pernapasan dan daya lihat bentos, serta dapat menghambat penetrasi cahaya yang masuk ke dalam perairan (Effendi, 2003 dalam Mushthofa et al., 2014).

Berdasarkan hasil pengukuran kekeruhan yang didapat, dapat disimpulkan bahwa pada perairan pesisir Kelurahan Mangunharjo, Kota Semarang mempunyai nilai kekeruhan berkisar antara 32,92 132 NTU. Nilai kekeruhan tertinggi terdapat pada stasiun 2. Tingginya nilai kekeruhan yang didapat, diduga akibat adanya aktivitas kapal nelayan yang keluar masuk pada stasiun II yaitu wilayah muara dan banyaknya limbah dari aktivitas masyarakat yang masuk ke perairan. Kekeruhan yang tinggi sangat berdampak negatif bagi kehidupan makrozoobentos. Menurut Gazali et al. (2015), kekeruhan dapat mengakibatkan menurunnya kadar oksigen terlarut dalam perairan sehingga suplai oksigen bagi 
organisme air seperti bentos akan terganggu. Kekeruhan juga mengakibatkan turunnya penetrasi cahaya matahari yang masuk ke dalam air, sehingga proses fotosintesis tumbuhan air (Hidrilla, ganggang air, dan alga) akan terganggu. Kondisi ini apabila terjadi secara terus menerus maka tumbuhan air akan menutupi dasar perairan yang merupakan habitat bentos dan lambat laun berdampak pada punahnya berbagai jenis makrozoobentos.

Berdasarkan hasil pengukuran kecepatan arus yang diperoleh, dapat disimpulkan bahwa perairan pesisir Kelurahan Mangunharjo memiliki kecepatan arus yang nilainya berkisar antara 0,07 $0,19 \mathrm{~m} / \mathrm{s}$. Kecepatan arus berpengaruh terhadap komunitas makrozoobentos, dikarenakan kecepatan arus akan mempengaruhi jenis substrat dasar perairan yang merupakan habitat makrozoobentos. Kecepatan arus juga akan berpengaruh terhadap faktor lingkungan lainnya seperti kecerahan, salinitas, oksigen terlarut (DO), karbondioksida, suhu, karakteristik organisme perairan seperti makrozoobentos, jumlah zat hara, tingkat sedimentasi dan pencemaran. Hal ini diperkuat oleh Saraswati et al. (2017), yang menyatakan bahwa arus memegang peranan penting dalam pergerakan zat hara yang ada dalam perairan. Zat hara berguna untuk pertumbuhan organisme akuatik. Peranan arus lainnya yaitu sebagai penyuplai makanan, kelarutan oksigen, dan sebagai penghilang karbondioksida maupun sisa - sisa produk biota lainnya.

Berdasarkan hasil pengukuran salinitas yang diperoleh, dapat disimpulkan bahwa perairan pesisir Kelurahan Mangunharjo mempunyai nilai salinitas berkisar antara $0-17 \%$. Nilai salinitas yang diperoleh termasuk dalam kategori tercemar, dikarenakan nilai salinitas berdasarkan baku mutu yang baik yaitu $10-15 \%$ o. Salinitas pada stasiun IV dan V memiliki nilai yang rendah. Hal ini disebabkan karena pada stasiun IV dan V merupakan perairan mangrove dan sungai. Kedua stasiun tersebut berjarak jauh dari muara dan merupakan lokasi aliran sungai dimana pengaruh air tawar lebih dominan sehingga salinitasnya rendah. Salinitas merupakan faktor pembatas bagi makrozoobentos. Salinitas berpengaruh terhadap penyebaran hewan makrozoobentos dan organisme perairan lainnya. Menurut Mudjiman (1981) dalam Izzah \& Efri (2016), kisaran salinitas yang baik bagi kehidupan makrozoobentos yaitu berkisar antara $15-45 \%$ o, karena pada perairan yang memiliki salinitas rendah ataupun tinggi dapat ditemukan makrozoobentos seperti Annelida, Gastropoda dan Bivalvia. Berdasarkan pengukuran salinitas yang sudah dilakukan dapat dikatakan bahwa pada perairan pesisir Kelurahan Mangunharjo memiliki kadar salinitas yang melebihi baku mutu air, namun berada dalam nilai yang cukup untuk mendukung kehidupan makrozoobentos.

Berdasarkan hasil pengukuran $\mathrm{pH}$ yang diperoleh, dapat disimpulkan bahwa perairan pesisir Kelurahan Mangunharjo mempunyai nilai $\mathrm{pH}$ yang berkisar antara 6,27 - 6,41. Nilai pH yang diperoleh pada stasiun I, III dan VI termasuk dalam kategori buruk dikarenakan nilai $\mathrm{pH}$ tidak memenuhi baku mutu sedangkan nilai $\mathrm{pH}$ yang diperoleh pada stasiun II, IV, dan V memenuhi baku mutu. Derajat keasamaan atau $\mathrm{pH}$ sangat penting dalam mendukung kelangsungan hidup organisme akuatik seperti makrozoobentos. Derajat keasamaan berpengaruh terhadap kelangsungan hidup dan pertumbuhan bentos. Nilai $\mathrm{pH}$ yang disukai organisme makrozoobentos yaitu kisaran $7-7,5$. Menurut Effendi (2003) dalam Paena et al. (2015), sebagian besar organisme air peka terhadap perubahan $\mathrm{pH}$ 
dan menyukai kisaran $\mathrm{pH} 7$ - 7,5 apabila nilai $\mathrm{pH}$ dalam suatu perairan $<7$ maka dapat menyebabkan turunnya keanekaragaman jenis makrozoobentos. Berdasarkan pengukuran $\mathrm{pH}$ yang sudah dilakukan dapat dikatakan bahwa pada perairan pesisir Kelurahan Mangunharjo memiliki nilai pH yang rendah sehingga kurang menguntungkan bagi kehidupan makrozoobentos.

Berdasarkan hasil pengukuran DO yang diperoleh, dapat disimpulkan bahwa perairan pesisir Kelurahan Mangunharjo mempunyai nilai DO yang berkisar antara 8,50 - 9,20 mg/L. Nilai DO yang diperoleh termasuk dalam kategori baik, dikarenakan memenuhi baku mutu. Nilai DO tertinggi didapatkan pada ekosistem muara dan mangrove. Tingginya nilai DO yang diperoleh dipengaruhi oleh proses difusi oksigen dan hasil fotosintesis oleh tumbuhan air (Sugianti \& Lismining, 2018). Semakin besar kandungan oksigen terlarut dalam suatu ekosistem, maka semakin baik pula bagi kehidupan makrozoobentos di ekosistem tersebut. Kadar oksigen terlarut lebih dari $5 \mathrm{mg} / \mathrm{L}$ merupakan kondisi batas minimum oksigen yang dapat mendukung keberlangsungan aktivitas organisme perairan. Hal ini diperkuat oleh Sastrawijaya (1991) dalam Ridwan et al. (2016), yang menyatakan bahwa kehidupan makrozoobentos masih dapat bertahan apabila oksigen terlarut dalam perairan minimum sebanyak 5 $\mathrm{mg} / \mathrm{l}$, selebihnya tergantung dari ketahanan organisme tersebut, derajat keaktifan, kehadiran bahan pencemar, temperatur air dan lain - lain. Kandungan oksigen terlarut akan mempengaruhi keanekaragaman bentos di suatu perairan, semakin tinggi kadar oksigen maka semakin besar kandungan oksigen dalam ekosistemnya. Kandungan oksigen dalam ekosistem yang besar akan berpengaruh positif terhadap kehidupan makrozoobentos.

\section{Component Plot in Rotated Space}

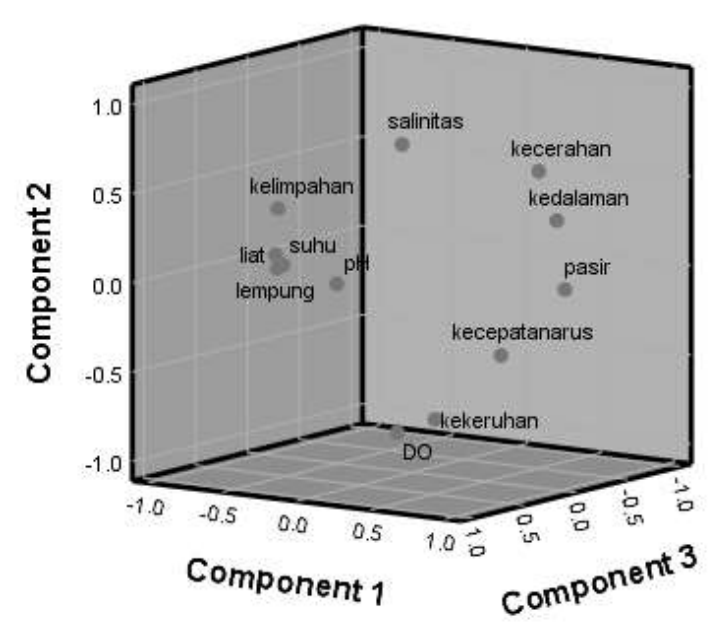

Gambar 1. Component Plot Hasil Principal Component Analysis (PCA)

Berdasarkan Principal Component Analysis (PCA) yang telah dilakukan diketahui bahwa variabel yang paling berpengaruh terhadap kelimpahan makrozoobentos pada perairan pesisir Kelurahan Mangunharjo yaitu suhu air, tekstur sedimen lempung, dan tekstur sedimen liat. Hal ini dapat dilihat berdasarkan letak antar variabel dalam component plot, dimana tiga variabel tersebut memiliki letak yang 
berdekatan dengan kelimpahan (Gambar 1). Kelimpahan makrozoobentos pada perairan pesisir Kelurahan Mangunharjo sangat dipengaruhi oleh suhu dan substrat/sedimen lempung dan liat dikarenakan variabel tersebut berperan dalam mendukung kelangsungan hidup makrozoobentos di suatu perairan Hal ini diperkuat oleh Yeanny (2007) dalam Dewiyanti et al. (2017), yang menyatakan bahwa makrozoobentos dapat hidup dan berkembang baik pada berbagai jenis substrat yang memiliki kesediaan makanan dan kehidupannya selalu dipengaruhi oleh kondisi fisika kimia perairan seperti suhu. Substrat dengan fraksi halus seperti lempung dan liat lebih banyak terdapat nutrien yang berguna bagi kehidupan makrozoobentos (Chusna et al., 2017). Tanah bertekstur lempung memiliki kemampuan menahan air dan luas permukaannya lebih besar daripada pasir sehingga menyediakan unsur hara yang tinggi (Hardjowigeno, 1992 dalam Permatasari et al., 2019). Tanah bertekstur liat akan mempermudah bagi makrozoobentos untuk membuat lubang dan kandungan bahan organik bagi kehidupannya juga melimpah (Ridwan et al., 2016).

Suhu berpengaruh sangat nyata terhadap kelimpahan dan keberadaan makrozoobentos dalam suatu perairan. Tingginya rendahnya suhu dapat mengakibatkan gangguan perkembangan daur hidup bentos dan mempengaruhi waktu regenerasi makrozoobentos. Hal ini diperkuat oleh Rahman (2009) dalam Choirudin et al. (2014), yang menyatakan bahwa pada kisaran suhu yang tinggi yaitu sekitar 33 $50{ }^{\circ} \mathrm{C}$ menyebabkan terjadinya gangguan perkembangan daur hidup, dan terjadinya penurunan suhu yang drastis dapat menyebabkan perpanjangan waktu pergantian generasi. Peningkatan suhu juga dapat mempengaruhi peningkatan kecepatan metabolisme dan respirasi organisme air yang selanjutnya menyebabkan peningkatan konsumsi oksigen (Effendi, 2003 dalam Choirudin et al., 2014).

\section{SIMPULAN}

Nilai indeks keanekaragaman $\left(\mathrm{H}^{\prime}\right)$ pada ke-enam stasiun dapat dikategorikan keanekaragaman sedang hingga rendah dengan nilai rerata $\mathrm{H}^{\prime}=0,79$. Kriteria nilai indeks keseragaman (E) secara keseluruhan mengindikasikan kondisi yang tertekan hingga stabil dengan nilai rerata $E=0,52$. Nilai indeks dominansi (C) menunjukkan adanya jenis yang mendominansi secara signifikan. Nilai indeks kesamaan dominan berada dalam kategori yang rendah. Tingkat pencemaran yang terjadi pada perairan pesisir Kelurahan Mangunharjo berdasarkan indikator kimia dan fisika dominan menunjukkan kondisi lingkungan yang sudah tercemar. Variabel yang paling mempengaruhi kelimpahan makrozoobentos pada perairan pesisir Kelurahan Mangunharjo adalah suhu air, tekstur sedimen lempung dan tekstur sedimen liat dengan nilai korelasi 0,597; 0,474 dan 0,453 yang menunjukan hubungan positif yang cukup kuat dengan kelimpahan.

\section{DAFTAR PUSTAKA}

Afif, J., S. Ngabekti \& T. A. Pribadi. (2014). Keanekaragaman Makrozoobentos Sebagai Indikator Kualitas Perairan Di Ekosistem Mangrove Wilayah Tapak Kelurahan Tugurejo Kota Semarang. Unnes Journal of Life Science, 3(1), 47-52.

Budi, D. A., Suryono, C. A., \& Ario, R. (2013). Studi Kelimpahan Gastropoda di Bagian Timur Perairan Semarang Periode Maret - April 2012. Journal of Marine Research, 2(4), 56-65. 
Choirudin, I. R., M. N. Supardjo \& M. R. Muskananfola. (2014). Studi Hubungan Kandungan Bahan Organik Sedimen Dengan Kelimpahan Makrozoobenthos Di Muara Sungai Wedung Kabupaten Demak. Journal of Management of Aquatic Resources, 3(3), 168-176. https://ejournal3.undip.ac.id/index.php/maquares/article/view/6708

Chusna, R. R. R., Rudiyanti, S., \& Suryanti, S. (2017). Hubungan Substrat Dominan Dengan Kelimpahan Gastropoda Pada Hutan Mangrove Kulonprogo, Yogyakarta (The Relation of dominant substrate to Gastropods Abundance in the Mangrove Forest of Kulonprogo, Yogyakarta). SAINTEK PERIKANAN : Indonesian Journal of Fisheries Science and Technology, 13(1), 19-23. https://doi.org/10.14710/ijfst.13.1.19-23

Dewiyanti, I., Fersita, M., \& Purnawan, S. (2017). Identifikasi makrozoobenthos di perairan Krueng Sabee, Krueng Panga, Krueng Teunom, Aceh Jaya. Prosiding: Seminar Nasional Biotik 2017, 946952.

Ernawati, S., Niartiningsih, A., Nessa, M. Na., \& Omar, S. B. A. (2013). Suksesi makrozoobentos di hutan mangrove alami dan rehabilitasi di Kabupten Sinjai Sulawesi Selatan. Jurnal Bionature, 14(1), 49-60.

Gazali, A., D. Suheriyanti \& Romaidi. (2015). Keanekaragaman Makrozoobentos sebagai Bioindikator Kualitas Perairan Ranu Pani-Ranu Regulo di Taman Nasional Bromo Tengger Semeru Macrozoobenthos Biodiversity as Bioindicator of Water Quality in Ranu. Seminar Nasional Konservasi dan Pemanfaatan Sumber Daya Alam, 86-91.

Holme, N. A. \& A. D. McIntyre. (1984). Methods for the Study of Marine Benthos. 1nternational Biological Programme. 2nd ed. Oxford: Blackwell Scientifc Publications. 41-65 pp.

Izzah, N. A., \& Roziaty, E. (2016). Keanekaragaman Makrozoobentos Di Pesisir Pantai Desa Panggung Kecamatan Kedung Kabupaten Jepara. Bioeksperimen: Jurnal Penelitian Biologi, 2(2), 140148. https://doi.org/10.23917/bioeksperimen.v2i2.2492

Kolaya, I., R. Hartati \& H. Endrawati. (2014). Kelimpahan Fitoplankton pada Tambak Tidak Produktif di Kelurahan Mangunharjo, Semarang. Journal of Marine Research, 3(4), 492-498.

Krebs, C.J. (1985). Ecology: The Experimental Analysis of Distribution and Abundance. Third edition. Haeper and Row Publisher: New York. 801 pp.

Meisaroh, Y., Restu, I. W., \& Pebriani, D. A. A. (2018). Struktur Komunitas Makrozoobenthos Sebagai Indikator Kualitas Perairan di Pantai Serangan Provinsi Bali. Journal of Marine and Aquatic Sciences, 5(1), 36-43. https://doi.org/10.24843/jmas.2019.v05.i01.p05

Munandar, Aris., M, Sarong A \& Sofyatuddin, K. (2016). Struktur Komunitas Makrozoobenthos Di Estuari Kuala Rigaih Kecamatan Setia Bakti Kabupaten Aceh Jaya. Jurnal Ilmiah Mahasiswa Kelautan Dan Perikanan Unsyiah, 1(3), 331-336.

Mushthofa, A., Muskananfola, M. R., \& Rudiyanti, S. (2014). Analisis Struktur Komunitas Makrozoobenthos Sebagai Bioindikator Kualitas Perairan Sungai Wedung Kabupaten Demak. Diponegoro Journal of Maquares, 3(1), 81-88. http://ejournal-s1.undip.ac.id/index.php/maquares

Nurlinda, S., Kasim, M., \& Nur, A. I. (2019). Struktur Komunitas Ikan Karang pada Terumbu Karang Buatan di Perairan Desa Tanjung Tiram Kecamatan Moramo Utara Kabupaten Konawe Selatan. Jurnal Manajemen Sumber Daya Perairan, 4(1), 75-82.

Nurrudin., A. Hamidah \& W. D. Kartika. (2015). Keanekaragaman Jenis Gastropoda di Sekitar Tempat Pelelangan Ikan (TPI) Parit 7 Desa Tungkal I Tanjung Jabung Barat. Biospecies, 8(2), 5160.

Odum, E. P. (1998). Dasar-dasar Ekologi. Gadjah Mada University Press: Yogyakarta. 697 hal.

Paena, M., Suhaimi, R. ntoni, \& Undu, M. C. (2015). Analisis konsentrasi oksigen terlarut (DO), pH, salinitas dan suhu pada musim hujan terhadap penuruan kualitas air perairan Teluk Punduh Kabupaten Pesawaran Provinsi Lampung. Prosiding: Seminar Nasional Kelautan X, 21 Mei 2015. http://prosidingseminakel.hangtuah.ac.id/index.php/ps/article/viewFile/30/25

Permatasari, I. R., Barus, B. S., \& Diansyah, G. (2019). Analisis Nitrat Dan Fosfat Pada Sedimen Di Muara Sungai Banyuasin, Kabupaten Banyuasin, Provinsi Sumatera Selatan. Jurnal Penelitian Sains, 21(3), 140-150. https://doi.org/10.36706/jps.v21i3.545

Pranoto, H. (2017). Studi Kelimpahan dan Keanekaragaman Makrozoobentos di Perairan Bedagai, Kecamatan Tanjung Beringin Kabupaten Serdang Bedagai. Jurnal Biosains, 3(3), 125-130. https://doi.org/10.24114/jbio.v3i3.8107

Purnami, A. T., Sunarto, \& Setyono, P. (2010). Study of Bentos Community Based on Diversity and Similarity Index in Cengklik DAM Boyolali. Jurnal Ekosains, 2(2), 50-65. 
Rachmawaty. (2011). Indeks Keanekaragaman Makrozoobentos Sebagai Bioindikator Tingkat Pencemaran Di Muara Sungai Jeneberang. Bionature, 12(2), 103-109.

Ridwan, M., Fathoni, R., Fatihah, I., \& Pangestu, D. A. (2016). Struktur Komunitas Makrozoobentos Di Empat Muara Sungai Cagar Alam Pulau Dua, Serang, Banten. Al-Kauniyah: Jurnal Biologi, 9(1), 57-65. https://doi.org/10.15408/kauniyah.v9i1.3256

Sahidin, A., Setyobudiandi, I., \& Wardiatno, Y. (2014). Struktur komunitas makrozoobentos di Perairan Pesisir Tangerang, Banten. Depik, 3(3), 226-233. https://doi.org/10.13170/depik.3.3.2150

Saraswati, N. L. G. R. A., Yulius., Rustam, A., Salim, H. L., Heriati, A., \& Mustikasari, E. (2017). Kajian Kualitas Air Untuk Wisata Bahari Di Pesisir Kecamatan Moyo Hilir Dan Kecamatan Lape, Kabupaten Sumbawa. Jurnal Segara, 13(1), 37-47. https://doi.org/10.15578/segara.v13i1.6421

Simanjuntak, M. (2007). Oksigen Terlarut dan Apparent Oxygen Utilization di Perairan Teluk Klabat, Pulau Bangka. Indonesian Journal of Marine Sciences, 12(2), 59-66. https://doi.org/10.14710/ik.ijms.12.2.59-66

Sugianti, Y., \& Astuti, L. P. (2018). Respon Oksigen Terlarut Terhadap Pencemaran dan Pengaruhnya Terhadap Keberadaan Sumber Daya Ikan di Sungai Citarum. Jurnal Teknologi Lingkungan, 19(2), 203-211. https://doi.org/10.29122/jtl.v19i2.2488

Suhendra, N., Hamdani, H., Hasan, Z., \& Sahidin, A. (2019). Struktur Komunitas Makroinvertebrata Di Wilayah Pantai Berkarang Karapyak Pesisir Pangandaran. Jurnal Perikanan Dan Kelautan, 10(1), 103-110.

Sujatmiko, B. K., \& Aunurohim. (2014). Studi Distribusi Makrofauna Benthos Di Zonasi Mangrove Pulau Poteran, Madura, Jawa Timur. Jurnal Sains Dan Seni Pomits, 2(1), 1-5.

Viza, R. Y. (2018). Eksplorasi dan visualisasi morfologis jenis moluska (gastropoda dan bivalvia) di sungai batang marangin. Biocolony: Jurnal Pendidikan Biologi Dan Biosains, 1(1), 1-6. 